Int. J. Plant Sci. 166(5):843-855. 2005.

(c) 2005 by The University of Chicago. All rights reserved.

$1058-5893 / 2005 / 16605-0013 \$ 15.00$

\title{
LEAF CUTICULAR MORPHOLOGY LINKS PLATANACEAE AND PROTEACEAE
}

\author{
Raymond J. Carpenter, ${ }^{1, *}$ Robert S. Hill, ${ }^{*} \dagger$ and Gregory J. Jordan $\ddagger$
}

\begin{abstract}
*School of Earth and Environmental Sciences, University of Adelaide, Adelaide, South Australia 5005, Australia; tCentre for Evolutionary Biology and Biodiversity, South Australian Museum, Adelaide, South Australia 5000, Australia; and ‡Department of Plant Science, University of Tasmania, P.O. Box 252-55, Hobart, Tasmania 7001, Australia
\end{abstract}

\begin{abstract}
The leaf cuticular morphology of extant species of Platanus was investigated using light and scanning electron microscopy. All species are shown to possess trichome bases of the same type as those commonly found in Proteaceae. Of particular significance are compound forms that consist of an annular surface scar associated with more than one underlying epidermal cell. These are found on the adaxial leaf surfaces of all species of Platanus and are also clearly evident on the abaxial surface of Platanus orientalis. This type of trichome base is therefore interpreted as the first detected nonreproductive morphological synapomorphy linking Proteaceae and Platanaceae. Also, the laterocytic, sometimes paracytic, or anomocytic arrangement of subsidiary cells in Platanus is distinct from the general state in Proteaceae, which is brachyparacytic and presumably derived. In Bellendena, possibly the most basal genus of extant Proteaceae, subsidiary cell arrangements resemble those of Platanus. These results are discussed with respect to leaf fossil records of Proteales, where it is concluded that the combination of brachyparacytic stomata and compound trichome bases is strong evidence for Proteaceae.
\end{abstract}

Keywords: Platanus, Platanaceae, Proteaceae, Bellendena, leaves, cuticles, trichomes, stomata, fossils, phylogeny.

\section{Introduction}

One recent intriguing revelation of molecular phylogenetic research is the association of Nelumbonaceae, Platanaceae, and Proteaceae (order Proteales). This order is a basal representative of the eudicot clade, which is united most distinctively by triaperturate or triaperturate-derived pollen (Donoghue and Doyle 1989; Doyle and Hotton 1991). Judd and Olmstead (2004) argued that this group should best be referred to as the "tricolpate clade," and this term is adopted here. The tricolpates comprise some $75 \%$ of angiosperm species (Drinnan et al. 1994).

Proteales include some of the world's most familiar plants: the lotus (Nelumbo spp.), sycamores, plane trees (Platanus spp.), and genera such as Banksia, Grevillea, Macadamia, and Protea (Proteaceae). Traditionally, Proteaceae (Johnson and Briggs 1975) and Nelumbonaceae were considered to be relatively isolated, and Takhtajan (1980) placed each as sole representatives at the ordinal level (Proteales and Nelumbonales). Platanaceae have been included within Hamamelidales (Takhtajan 1980; Cronquist 1981; Schwarzwalder and Dilcher 1991). However, there is now strong support from DNA sequences (Drinnan et al. 1994; Hoot and Douglas 1998; Hoot et al. 1999; Savoleinen et al. 2000; Hilu et al. 2003) that Platanaceae and Proteaceae are sister taxa, with the theoretical option that Platanus could be included as a (basal) member of Proteaceae (APG II 2003). The status of Nelumbonaceae as a member of Proteales is less emphatic, with relatively weak support from molecular data (Kim et al.

${ }^{1}$ Author for correspondence; e-mail rcarpenter@ozemail.com.au. Manuscript received December 2004; revised manuscript received April 2005.
2004) and no support from gynoecial features (Endress and Igersheim 1999) and floral development and anatomy (Hayes et al. 2000). Indeed, branching orders among the earlydiverging tricolpates are generally not well resolved.

Extant Platanaceae are composed of seven species of trees, five of which occur in North America, one in Eurasia (Platanus orientalis), and one confined to Vietnam/Laos (Platanus kerrii) (Nixon and Poole 2003). All but the latter belong to subgenus Platanus and have palmately lobed, deciduous leaves. By contrast, P. kerrii has simple evergreen leaves and has been assigned to subgenus Castaneophyllum (Leroy 1982). Although the infrageneric phylogeny has not yet been determined, Nixon and Poole (2003) proposed that the American species of subgenus Platanus could be morphologically differentiated into eastern and western groups, and they tentatively placed $P$. orientalis in the western group. Platanus $\times$ acerifolia is recognized as a hybrid between $P$. orientalis and Platanus occidentalis, a species in their eastern group. Along with its phylogenetic significance at the base of the tricolpate clade, the family is of considerable interest because it has a strong fossil record in the Northern Hemisphere, including well-preserved specimens of both reproductive structures and leaves. The oldest fossils known are Early Cretaceous and include reproductive axes bearing sessile inflorescences and lacking dispersal hairs on the achenes (Crane et al. 1993).

Extant Proteaceae are composed of 79 genera and approximately 1700 species, nearly all of which are confined to the Southern Hemisphere (Johnson and Briggs 1975; Douglas 1995). At present, seven subfamilies are recognized, and although molecular analyses indicate that most are essentially monophyletic, relationships within subfamily Grevilleoideae 
are especially unclear (Hoot and Douglas 1998). Numerous well-preserved fossil Proteaceae leaves from Australia (Cookson and Duigan 1950; Hill and Christophel 1988; Hill et al. 1995; Carpenter and Jordan 1997; Jordan et al. 1998), New Zealand (Pole 1998), and South America (Frenguelli 1943) have been described and compared with extant species. The oldest known macrofossils with cuticular preservation are lobed Banksia-like leaves from the Late Paleocene of New South Wales (Carpenter et al. 1994), but pollen evidence indicates that most modern subfamilies had differentiated by the Late Cretaceous (Dettmann and Jarzen 1998). Based on estimates from molecular evidence, the sister relationship with Platanaceae implies that at least the stem group of Proteaceae had diverged by $108 \mathrm{Ma}$ (Wikström et al. 2001). Pole (1992, 2000), Johnson (cited as personal communication to Drinnan et al. [1994],) and Parrish et al. (1998) have noted Platanaceae-like leaves in New Zealand and Australian Cretaceous floras but without supporting cuticular evidence. No convincing Proteaceae fossils have been described from the Northern Hemisphere.

Leaves and leaf cuticles provide numerous features that can be included as characters in data sets for phylogenetic analysis (Nandi et al. 1998; Doyle and Endress 2000). These include venation and teeth (Hickey and Wolfe 1975) and trichomes, stomatal arrangements, and glands (Hill and Jordan 1993). The morphology of leaf cuticles of Platanus species was described by Baas (1969), Brett (1979), Metcalfe and Chalk (1979), Upchurch (1984), and Kvaček et al. (2001) on the basis of light microscopy (LM). However, no detailed scanning electron microscopy (SEM) studies of extant species have been published. Leaf cuticles of numerous species of Proteaceae have been illustrated and described by numerous authors, including Carpenter (1994; R. J. Carpenter, unpublished data) and Gonzalez et al. (2004).

In this article, we report on the leaf cuticles of extant Platanaceae using LM and SEM and compare their morphology to states known in Proteaceae, especially with regard to characters that might be of phylogenetic significance. Then we discuss the implications of these findings with respect to the leaf fossil record.

\section{Material and Methods}

Mature leaves from extant species of Platanus were obtained from the Florida Museum of Natural History, University of Florida (UF); MO; the School of Earth and Environmental Sciences, University of Adelaide (UA); and from specimens cultivated in Adelaide, South Australia. Both inner and outer cuticular surfaces were examined using LM and SEM, and data pertaining to stomatal distribution, subsidiary cell arrangement, trichome base morphology, and surface ornamentation were recorded (Dilcher 1974). The Platanus cuticles were then compared with collections of Proteaceae held at UA. These include species from all of the extant genera, with multiple species of all large genera. Because of its apparent basal position in Proteaceae (Hoot and Douglas 1998), Bellendena was studied in some detail. Platanus taxonomy follows Nixon and Poole (2003), and that of Proteaceae follows Douglas (1995). The complete list of species illustrated in this study is shown in table 1 . To gain a greater appreciation of the potential phylogenetic significance of cuticular characters in Platanaceae and Proteaceae, wider comparisons were made using the large leaf cuticle collection housed

\section{Table 1}

Specimens of Platanaceae and Proteaceae Illustrated in This Study

\begin{tabular}{|c|c|c|}
\hline Species & Specimen/collector (source) & Area of origin \\
\hline \multicolumn{3}{|l|}{ Platanaceae: } \\
\hline Platanus gentryi Nixon \& Poole & H. S. Gentry 5862 (MO 1252828) & Sinaloa, Mexico \\
\hline Platanus kerrii Gagnep. & D. K. Harder 5877 (UF) & Vietnam \\
\hline Platanus mexicana Moric. var. mexicana & As P. mexicana; R. N. Schwarzwalder 1039 (UF) & Veracruz, Mexico \\
\hline Platanus occidentalis L. var. occidentalis & As $P$. occidentalis; E/M/133 (UA) & Indiana \\
\hline \multicolumn{3}{|l|}{ Platanus occidentalis L. var. palmeri (Kuntze) } \\
\hline Nixon \& Poole ex Geerinck & As $P$. glabrata Fern.; R. N. Schwarzwalder 1055 (UF) & Tamaulipas, Mexico \\
\hline Platanus orientalis $\mathrm{L}$. & Cultivated, Adelaide Botanical Gardens & Eurasia \\
\hline Platanus racemosa Nutt. var. racemosa & As $P$. racemosa; J. T. Howell 51067 (MO 04580956) & California \\
\hline Platanus racemosa Nutt. var. wrightii & $\begin{array}{l}\text { As } P . \text { wrightii Wats.; R. G. Walter } 11102 \\
\quad(\mathrm{MO} \mathrm{3442078)}\end{array}$ & Arizona \\
\hline Platanus $\times$ acerifolia (Ait.) Willd. & Cultivated, Adelaide University (UA) & ( $P$. orientalis $\times P$. occidentalis \\
\hline \multicolumn{3}{|l|}{ Proteaceae: } \\
\hline \multicolumn{3}{|l|}{ Subfamily Bellendenoideae: } \\
\hline Bellendena montana $\mathrm{R} . \mathrm{Br}$. & E/TAS/052 (UA) & Tasmania \\
\hline \multicolumn{3}{|l|}{ Subfamily Proteoideae: } \\
\hline Adenanthos cuneatus Labill. & UA & Western Australia \\
\hline \multicolumn{3}{|l|}{ Subfamily Grevilleoideae: } \\
\hline Banksia conferta A. S. George var. conferta & E/3053 (UA) & Western Australia \\
\hline Hicksbeachia pilosa P. Weston & Cultivated, Tolga, Queensland (UA) & North Queensland \\
\hline Knightia excelsa $\mathrm{R}$. Br. & E/1491 (UA) & New Zealand \\
\hline Musgravea heterophylla L. S. Smith & $\mathrm{E} / 1489$ (UA) & North Queensland \\
\hline
\end{tabular}

Note. Platanus taxonomy follows Nixon and Poole (2003). 
at UA. Taxa studied included Nelumbo and species of Berberidaceae, Menispermaceae, Papaveraceae, Ranunculaceae, and Sabiaceae, which are other early-diverging tricolpates (Drinnan et al. 1994; Hilu et al. 2003). Less comprehensive comparisons were made with the very large core tricolpate clade, but species from more than 170 families were examined, including Gunneraceae. Gunnerales occupy a position as sister to the rest of the core tricolpates and share features of perianth merosity with early-diverging tricolpates (Soltis et al. 2003).

Cuticles were prepared for microscopy by cutting small sections of leaf from the leaf margin and then dissolving their mesophyll tissues with $10 \%$ aqueous chromium trioxide, sometimes with gentle heating. If persistent trichomes obscured the leaf surface, further samples were processed after physically removing trichomes with adhesive tape. The cleared cuticle envelopes were then rinsed, soaked briefly in $5 \%$ aqueous ammonia, and stained with safranin $O$. They were then mounted in phenol glycerine jelly for examination using LM or mounted on aluminium stubs and gold coated for SEM. SEM was performed using a Philips XL 30 operated at $10 \mathrm{kV}$. For LM, cuticles were photographed using an Olympus DP10 digital camera attached to a Zeiss Axioskop microscope.

\section{Results}

\section{Trichomes and Trichome Bases}

Candelabriform trichomes with whorls of arms (fig. 1A, $1 B$ ) were observed on the leaves of all species of Platanus. In Platanus orientalis, Platanus occidentalis var. occidentalis, and Platanus $\times$ acerifolia, these are restricted to major veins on the abaxial surface, whereas in all other species, a dense vesture of trichomes covers the abaxial surface. These were usually readily detached during cuticle preparation but sometimes persist, most obviously in Platanus gentryi. Trichome bases were much more abundant on the abaxial leaf surface of all species, where they are mostly confined to the veins (fig. $1 C-1 G$ ) but also occur within small areoles (among the stomata), especially in Platanus kerrii (fig. $1 D$ ) and $P$. gentryi (fig. 1G). Although there is evidently a range of forms, two extremes of trichome base morphology can be discriminated. In the first, a rounded scar of the order of $20-30 \mu \mathrm{m}$ in diameter appears as a thickened ring that encompasses parts of two or more, often smaller, epidermal cells. The cuticle over these cells is usually also distinct from that over the surrounding epidermal cells in being thicker (darker staining) and not striated. These trichome bases occur on the adaxial surface of all Platanus species (fig. 2A-2J), where there are often two to eight such basal cells. On the inner cuticle surface, these cells may contribute to an aperture (or thin cell wall/middle lamellar region) that corresponds with the trichome insertion point (fig. 2J). Otherwise, this aperture appears to be effectively sealed over by cuticle deposition, usually associated with epidermal cell division. Thus, the typical glabrous adaxial cuticles of Platanus leaves exhibit relatively large-diameter trichome bases that are associated with more than one cell. Similarly, where usually smaller trichome bases associated with only one cell do occur on the adaxial surface, they occur in combination with persistent trichomes.
These were observed in Platanus racemosa var. wrightii (figs. $1 B, 2 G)$.

On the abaxial surfaces of Platanus leaves, trichome bases are usually more difficult to interpret because the cuticles are thinner. Large-diameter bases associated with distinct basal epidermal cells are obvious only in $P$. orientalis (fig. $1 F$; fig. $3 A, 3 B$ ) but also appear to be common in $P$. occidentalis var. occidentalis and Platanus $\times$ acerifolia (fig. $3 C$ ), the other taxa that are near glabrous. In $P$. racemosa var. racemosa, $P$. racemosa var. wrightii, and $P$. gentryi (fig. $1 G$ ), they are distributed among the stomata but are much less common than a second smaller-diameter (ca. $10 \mu \mathrm{m}$ ) form of trichome base. These also predominate in $P$. occidentalis var. palmeri (fig. 1C), P. kerrii (fig. 1D), and Platanus mexicana var. mexicana (fig. 1E), where the larger forms appear to be mostly restricted to the major veins. The smaller types usually appear to be rooted in the epidermis without their bases encompassing surrounding cells (fig. $1 C-1 E, 1 G$ ). When such a trichome is physically detached, its base may appear as a thickened, more or less cylindrical papilla-like stalk (fig. $1 E$; fig. $3 D$, $3 E)$. On the inner cuticle surface, the positions of these trichomes are also marked by apertures (fig. $3 F, 3 G$ ).

Examination of mature leaves of Proteaceae using a binocular microscope demonstrated that if present, trichomes are much more abundant on the abaxial surface, where they are sometimes confined to the major vein(s). These are never candelabriform, being usually simple (fig. $3 H$ ) and in some taxa with a two-armed terminal cell. Even if leaves appear glabrous at maturity, trichome bases are often observable using LM. Trichome bases associated with multiple (more than two) epidermal cells are especially widespread within the clade comprising subfamilies Grevilleoideae (fig. 4A-4C), Carnarvonioideae, and Sphalmioideae but were also observed in a few species elsewhere (e.g., Faurea spp., subfamily Proteoideae). No such bases were observed in Nelumbo or other early-diverging tricolpates or in Gunnera, but similar forms were observed in certain higher core tricolpates. Most notably, these included species from the asterid I clade (Avicenniaceae: Avicennia; Myoporaceae: widespread in Eremophila; Solanaceae: Duboisia; Verbenaceae: Gmelina). Isolated occurrences were observed elsewhere in asterids (Asteraceae: Olearia) and rosids (Myrtaceae: Rhodomyrtus). Interestingly, small, thickened, cylindical trichome base stalks like those in Platanaceae also occur in some Proteaceae: tribe Banksieae of Grevilleoideae (fig. 4D) and some members of subfamily Proteoideae (fig. 4E). These are also like those of Platanus in being observable on the inner surface as a smalldiameter aperture (fig. 4F).

\section{Stomata}

The stomata of all extant species of Platanus are confined to distinct, small areolar regions on the abaxial leaf surface, each containing ca. 10-20 stomata (fig. 1C-1G). Subsidiary cell arrangements are variable and often difficult to interpret but include typically anomocytic and laterocytic states (fig. $3 B, 3 C, 3 F, 3 G$; fig. $4 G)$ as well as apparently paracytic states (fig. 4G). In the laterocytic case, there are often five or six lateral subsidiary cells, and the cell walls between the subsidiary cells and normal epidermal cells are often poorly defined (fig. 4H, 4I). The guard cells overlie the subsidiary 

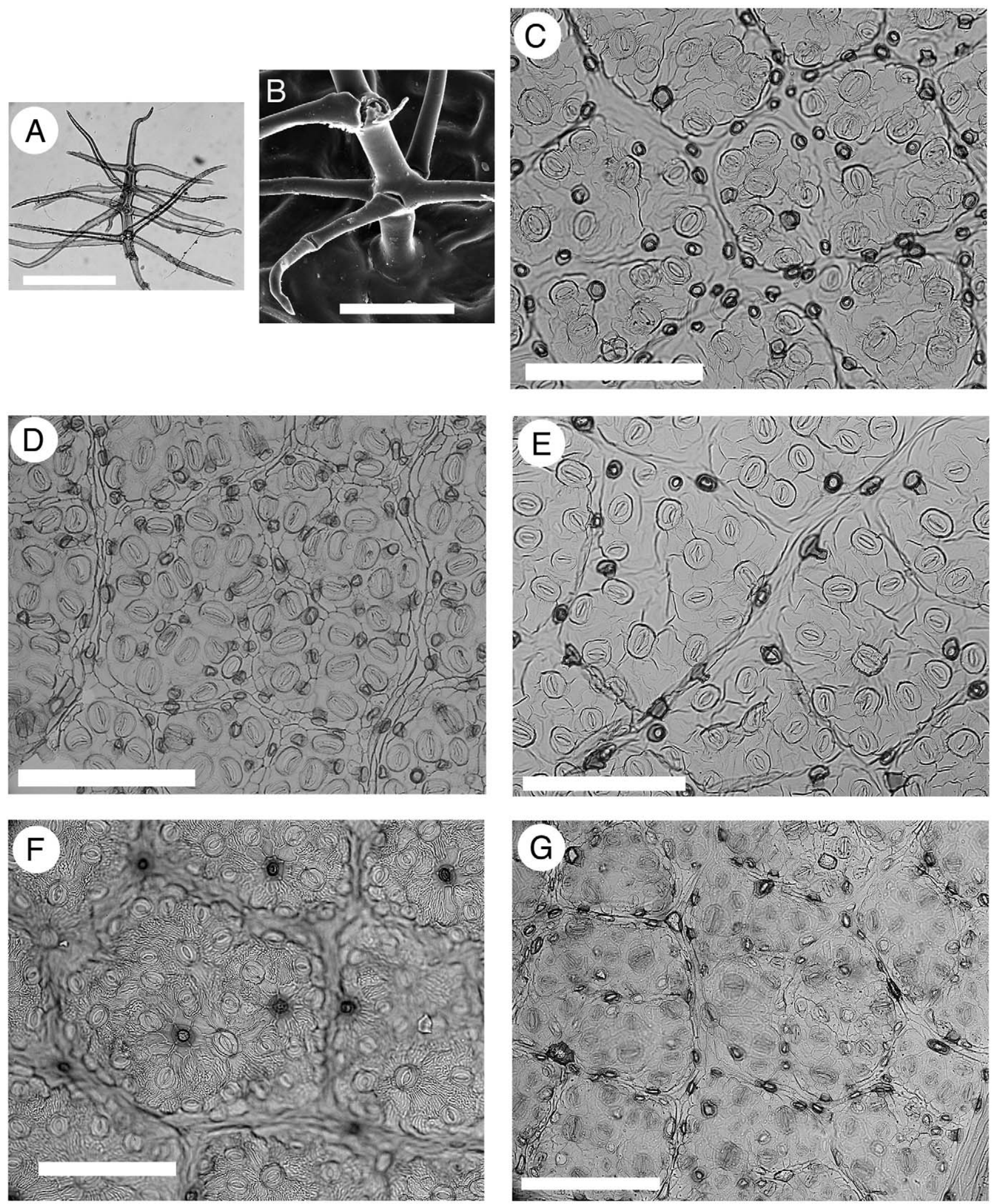

Fig. 1 Trichomes $(A, B)$ and LM images of abaxial leaf cuticles of Platanus $(C-G)$ showing stomata distributed in areoles and trichome bases. Scale bars $=200 \mu \mathrm{m}$ for $A, C-G ; 50 \mu \mathrm{m}$ for B. A, Candelabriform trichome from the abaxial surface of Platanus racemosa var. wrightii. Note whorls of arms. B, SEM image of adaxial surface of $P$. racemosa var. wrightii showing basal attachment of trichome. C, Platanus occidentalis var. palmeri. Note small, thickened trichome bases mostly on veins. D, Platanus kerrii. Note relatively large stomata and trichome bases among stomata. E, Platanus mexicana var. mexicana. Note trichome bases mostly on veins. F, Platanus orientalis. Note prominent striations and larger trichome bases obviously associated with multiple cells. G, Platanus gentryi. The cuticle was prepared following removal of persistent trichomes. Note relatively small stomata, trichome bases distributed among stomata, and some larger bases associated with several cells (one at left). 

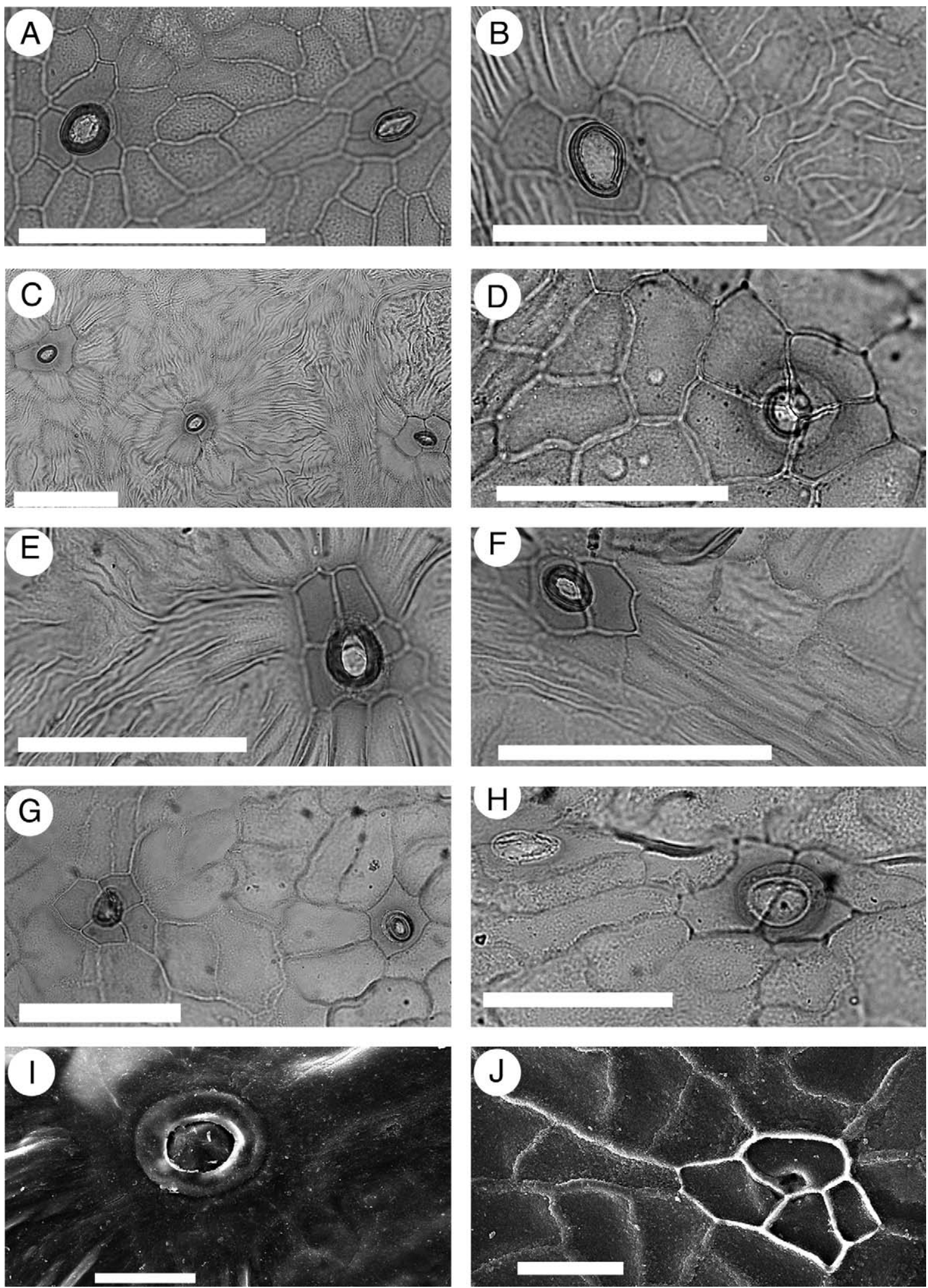

Fig. 2 LM $(A-H)$ and SEM $(I, J)$ images of adaxial leaf cuticles of Platanus showing compound trichome bases, many of which are associated with four cells. Scale bars $=100 \mu \mathrm{m}$ for $A-G ; 50 \mu \mathrm{m}$ for $H ; 20 \mu \mathrm{m}$ for $I, J$. A, Platanus occidentalis var. palmeri. B, Platanus kerrii. C, Platanus mexicana var. mexicana. D, Platanus orientalis. E, P. occidentalis var. occidentalis. F, Platanus $\times$ acerifolia. G, Platanus racemosa var. wrightii. Note that the trichome base at right is associated with only one cell. H, Platanus gentryi. I, P. racemosa var. wrightii showing annular surface scar. $J$, Platanus $\times$ acerifolia. Inner surface showing trichome base attachment site associated with four cells. 

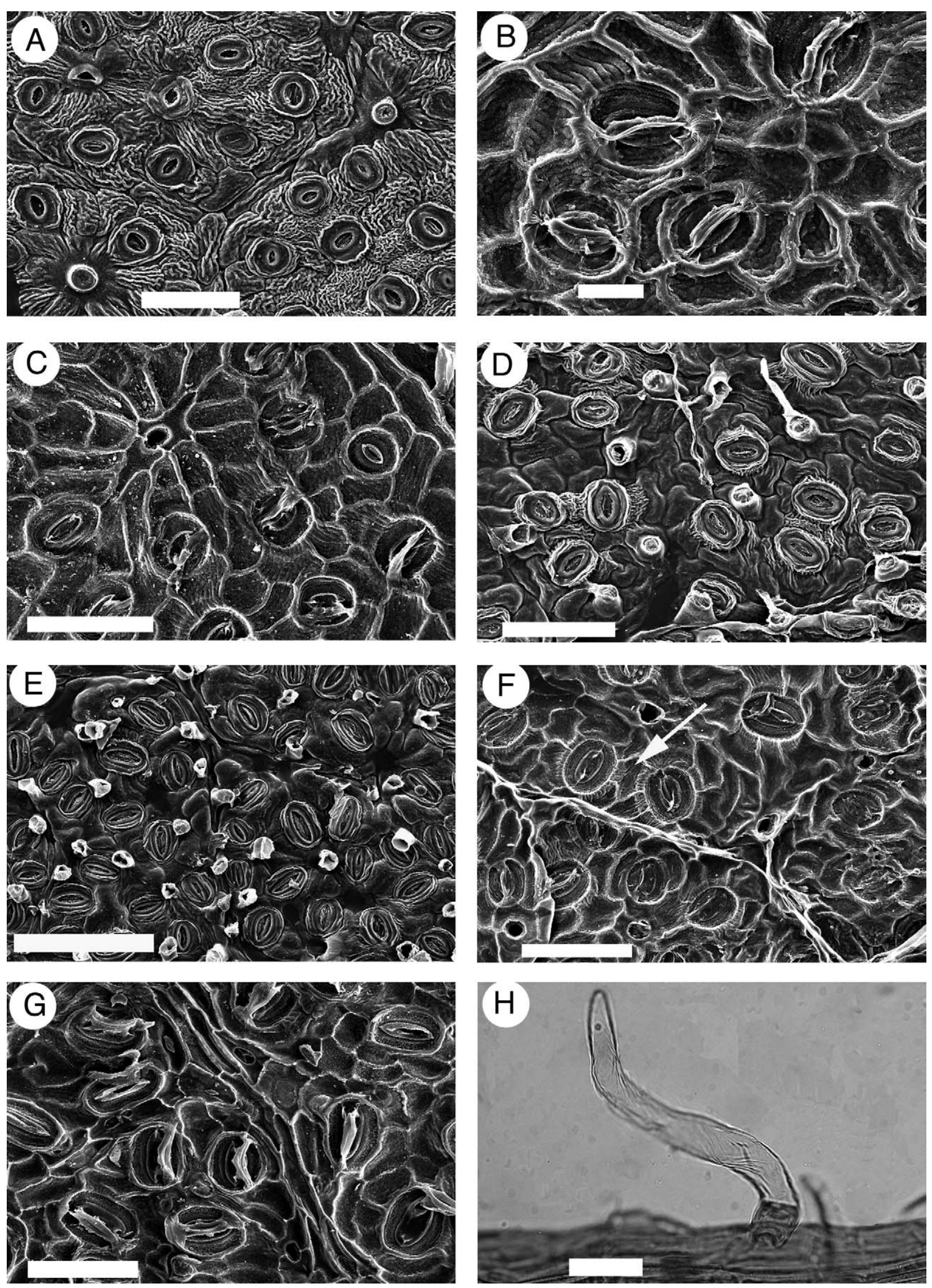
cells (fig. 4I). Each stomate has a raised ledge or rim over the guard cell regions, which is itself surrounded by raised ornamentation (fig. $3 A, 3 D, 3 E$ ). Platanus stomata may be of variable size, even within the same areole. Overall, $P$. kerrii consistently has the largest stomata (fig. $1 D$; fig. $3 E, 3 G$ ), while $P$. gentryi has the smallest (fig. $1 G$ ).

Paracytic (usually brachyparacytic) stomata occur throughout Proteaceae (fig. $4 A, 4 D, 4 F$ ), although the subsidiary cells may rarely be very narrow and difficult to interpret, especially in species with very thin or very thick cuticles. Bellendena is an exception because apart from some stomata that appear paracytic, the typical state is one in which several cells surround the guard cells in a more or less laterocytic (or anomocytic) arrangement (fig. 5A-5C). As observed in Platanus (fig. 4G-4I), the subsidiary cells of Bellendena underlie the guard cells (fig. 5C), and what are interpreted to be cell walls between the subsidiary cells and normal epidermal cells are not well defined (fig. 5A-5C). In the other available early-diverging tricolpates (including Nelumbo), the stomata are consistently nonparacytic, being usually anomocytic. Most core tricolpates examined, including Gunnera, also exhibit nonparacytic stomata.

\section{Other Features}

The leaf cuticles of all species of Platanus are quite thin, especially on the abaxial side, even in the evergreen P. kerrii. Platanus gentryi and both varieties of $P$. racemosa appear to have the thinnest cuticles. The cuticle surfaces of all Platanus species exhibit striations, although only in $P$. orientalis (figs. $1 F, 3 A$ ) and to a lesser extent Platanus $\times$ acerifolia are they as prominent on the abaxial surface as on the adaxial surface. In the other taxa, the abaxial striations are typically fine and weak and are confined to areas around the stomata (fig. $1 C-1 E, 1 G$; fig. $3 D, 3 E$ ). In all taxa, the striations are reflected to a greater or lesser extent on the inner surface of the abaxial cuticle (fig. $3 B, 3 C, 3 F, 3 G$ ). Striations similar to those of Platanus also occur in Proteaceae, especially within the clade comprising subfamilies Grevilleoideae, Carnarvonioideae, and Sphalmioideae.

\section{Discussion}

The molecular evidence for the closeness of the relationship between Platanaceae and Proteaceae has promoted the search for previously obscure morphological synapomor- phies. Doyle and Endress (2000) listed the links between Platanaceae and Proteaceae as orthotropous ovules, free nuclear endosperm development, and large embryos. In particular, Floyd et al. (1999) stressed the similarity of these features in Platanus and Bellendena, the genus that may be basal in the family (Hoot and Douglas 1998). Hoot et al. (1999) also pointed to the two families sharing a basically tetramerous floral arrangement, although Proteaceae perianths may in fact be dimerous (Douglas and Tucker 1996; Doyle and Endress 2000; Soltis et al. 2003).

\section{Trichomes and Trichome Bases}

Trichome bases of Platanus have been described by Upchurch (1984) and Kvaček et al. (2001) as being compound, i.e., with a rounded scar situated over the junction of two or more modified, underlying epidermal cells. These are also known in extinct Platanaceae species (fig. 8C of Kvaček and Manchester 2004). Here we demonstrate that the same bases are found in Proteaceae (cf. figs. 2, 3B with fig. 4A-4C). We therefore conclude that these represent a further morphological synapomorphy linking the families and the first to be detected based on nonreproductive traits. Lange (1978) recognized the distinctiveness of the trichome bases in Proteaceae and to our knowledge was the first to note a related structure in Platanus. However, perhaps not surprisingly at the time, he was apparently somewhat dismissive of the possible significance of this. This was despite him reporting a similar form of trichome base on only one (an unspecified Araliaceae from New Guinea) of the 4000 diverse leaf fragments of Australian region angiosperms that he examined. In our collection, we observed similar forms in only a few taxa of core tricolpates. These occurrences are explained most parsimoniously as secondary derivations, but this requires further testing with larger data sets. Of particular interest is their presence in taxa that are representatives of a strongly supported $(100 \%)$ group within the euasterid I or lamiid clade (Bremer et al. 2002). This observation provides independent validation that such trichome bases are of phylogenetic utility. The smaller-diameter, cylindrical form of trichome base stalks and cuticular striations that occur in some Proteaceae could also be homologous with those that occur in Platanus. However, this interpretation would require multiple losses of these structures in Proteaceae. Also, such features are less distinctive and may occur widely in angiosperms. Striations were also noted by Kvaček et al. (2001) in Platanus and in certain rainforest Proteaceae within the clade

Fig. 3 SEM images of abaxial leaf cuticles of Platanus $(A-G)$ and LM image of Bellendena montana (Proteaceae) trichome $(H)$. Scale bars $=50 \mu \mathrm{m}$ for $A, C-H ; 20 \mu \mathrm{m}$ for B. A, Platanus orientalis. Note surface striations, raised ledges around stomata, and trichome bases (one at lower left). $B, P$. orientalis. Inner surface showing reflected striations, stomata, and the attachment site of a trichome base associated with four cells. C, Platanus $\times$ acerifolia. Inner surface. Note trichome base attachment site associated with two cells at upper center left and variable arrangements of subsidiary cells. D, Platanus occidentalis var. palmeri. Note ornamentation and fine striations around the raised stomatal ledges and small, cylindrical trichome base stalks. E, Platanus kerrii. Note especially the abundant, small, cylindrical trichome base stalks. F, $P$. occidentalis var. palmeri. Inner surface. Note the reflections of the fine striations around the stomata, pores marking the positions of trichome attachments, and the variable subsidiary cell arrangements. The cell arrowed between two stomata is interpreted as a shared neighboring cell so that the striated regions on each side mark the positions of subsidiary cells, each with poorly defined walls between the neighboring cell. $G, P$. kerrii. Inner surface. Note variable subsidiary cell arrangements and positions of trichome attachments, some of which are poral. $H$, Simple trichome from leaf base. Including the basal cell in the epidermis, the trichome is three celled, with a thick stalk cell and thinner, elongated terminal cell. 

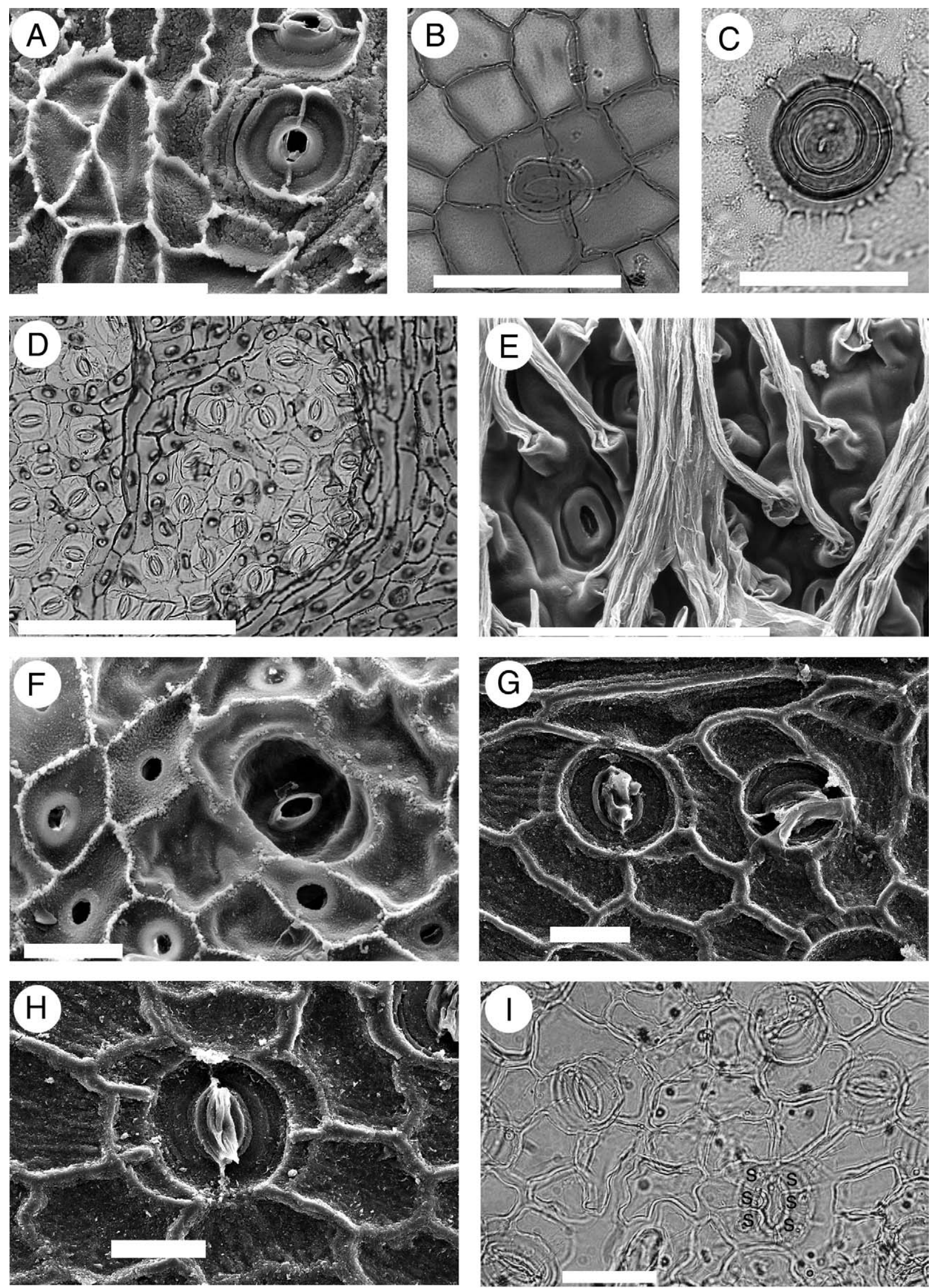
comprising subfamilies Grevilleoideae, Carnarvonioideae, and Sphalmioideae by Carpenter (1994) and Carpenter and Jordan (1997). Thickened, cylindrical, trichome base stalks in Proteaceae were investigated in Banksia and Dryandra by Cookson and Duigan (1950), and Johnson and Briggs (1975) also noted their presence in the closely related Musgravea.

The ontogeny of leaves and development and shedding of trichomes in Proteaceae and Platanaceae require further investigation. These might clarify the precise relationship between leaf and trichome maturation, the onset of the contraction of cell contents, and the form of the basal cells (Carpenter 1994). At present, it seems likely that the compound bases develop through epidermal cell divisions after the associated trichomes have been shed early in the development of the leaf. The porelike apertures observed in the inner cuticle surface of Platanus species and Banksieae indicate that the associated small trichomes retain contact with the underlying leaf tissues. In some cases, much larger pores are visible, apparently in association with large trichomes, as for instance in species of Gevuina and Hicksbeachia (see Carpenter 1994). In other cases, cellular contact seems to be retained with large trichomes through tiny apertures in the cuticle at the base of the trichome, as in Diastella (R. J. Carpenter, unpublished data).

The nature and distribution of the various types of trichome and trichome bases may also be of ecological and phylogenetic significance. All species of Platanus possess foliar candelabriform trichomes, which have variable density and persistence among the species (Baas 1969; Nixon and Poole 2003). On the abaxial leaf surface, these can form a pubescent mesh that completely conceals the stomata and that may be important for controlling transpiration. Metcalfe and Chalk (1979) reported that uniseriate and glandular capitate hairs also occur in Platanus. Baas (1969) concluded that these types are deciduous at a very early stage of leaf development and found none on the mature leaves of the species he investigated. We also did not observe any. A large, peltate, glandular type of trichome characterizes the extinct subgenus Glandulosa (Kvaček et al. 2001; Kvaček and Manchester 2004). Trichomes are found in all genera of Proteaceae but sometimes only on very young buds (Johnson and Briggs 1975). These are three celled (including the basal cell in the epidermis) and always uniseriate, and in species of some genera (notably of tribe Grevilleeae), the terminal cell is two branched (Johnson and Briggs 1975; Metcalfe and Chalk
1979). Candelabriform trichomes do not occur in Proteaceae. However, trichomes with suppressed branches occur on Platanus achenes (Nixon and Poole 2003). Thus, assuming that candelabriform trichomes occurred in the basal platanoid taxon, a possible evolutionary pathway for the simple trichomes in Proteaceae could be through reduction of more complex forms.

\section{Stomata}

Our interpretation of the stomatal complex of Platanus agrees with the descriptions of Brett (1979), Baas (1969), and Kvaček et al. (2001). Brett (1979), who investigated the ontogenetic development of Platanus leaves, found that polar cells are not involved in cell divisions in Platanus and that overall, there tend to be numerous (often five or six) small lateral subsidiary cells, associated especially with the larger (first formed) stomata. Brett (1979) and Baas (1969) also clearly showed that the guard cells overlie the subsidiary cells. The stomata of Bellendena montana are unique in Proteaceae in not being (brachy)paracytic, as also noted by Carpenter and Jordan (1997) and Jordan et al. (1998). Rather, they typically appear to be laterocytic, also with the subsidiary cells underlying the guard cells. The septum-like walls that sometimes occur between the subsidiary cells suggest that the arrangement may be of the subdivided paracytic type and not laterocytic (Den Hartog and Baas 1978; Baranova 1983). However, the fact that the cell outlines are usually of irregular shape and do not simply appear as one subdivided cell alternatively indicates that these are individual cells formed during the differentiation of the stomatal complexes. Additionally, the indistinct walls extend to the adjacent epidermal cells, as in Platanus. Considering the basal position of Bellendena in Proteaceae, the similarity between Bellendena and Platanus may represent a shared ancestral state. From the data presented by Doyle and Endress (2000), subsidiary cell arrangements elsewhere in putative basal members of early-diverging tricolpate families (including Nelumbo) are nonparacytic, except in Menispermaceae (as Tinospora caffra (Miers) Troupin). We agree with these data, except that in our large collection of Menispermaceae cuticles, including other Tinospora species, all are typically nonparacytic. Overall, we conclude that the brachyparacytic state is a synapomorphy for Proteaceae excluding Bellendena.

Fig. 4 Images of Proteaceae cuticles $(A-F)$ and of Platanus orientalis $(G, H)$ and Platanus occidentalis var. occidentalis $(I)$ stomata. Scale bars $=50 \mu \mathrm{m}$ for $A, C, I ; 100 \mu \mathrm{m}$ for $B, D, E ; 20 \mu \mathrm{m}$ for $F-H$. A, Knightia excelsa. SEM image of inner abaxial surface. Note the trichome base attachment point associated with four cells at left and a paracytic stomate. $B$, LM image of adaxial cuticle of Banksia conferta var. conferta showing an annular trichome base associated with eight cells. C, LM image of adaxial cuticle of Hicksbeachia pilosa showing an annular trichome base. D, LM image of abaxial cuticle of B. conferta var. conferta showing distribution of paracytic stomata in an areole and abundant, small, cylindrical trichome base stalks. E, Adenanthos cuneatus. SEM image of outer abaxial surface. Note trichomes with thickened, cylindrical base stalks among the stomata. F, Musgravea heterophylla. SEM image of inner abaxial surface. Note the paracytic stomate and the positions of trichomes marked by pores. G, SEM image of inner abaxial surface showing two stomata with different subsidiary cell arrangements. The stomate at left appears paracytic with small, narrow subsidiary cells that have poorly defined walls separating them from adjacent epidermal cells whereas that at right may be termed anomocytic. $H$, SEM image of inner abaxial surface showing stomate with $3+2$ laterocytic subsidiary cell arrangement. The walls between these and adjacent epidermal cells are generally not as prominent as those between normal epidermal cells, especially that at lower right. I, LM image of abaxial cuticle showing that although cell wall traces are weak, subsidiary cells $(S)$ underlie the guard cells. 

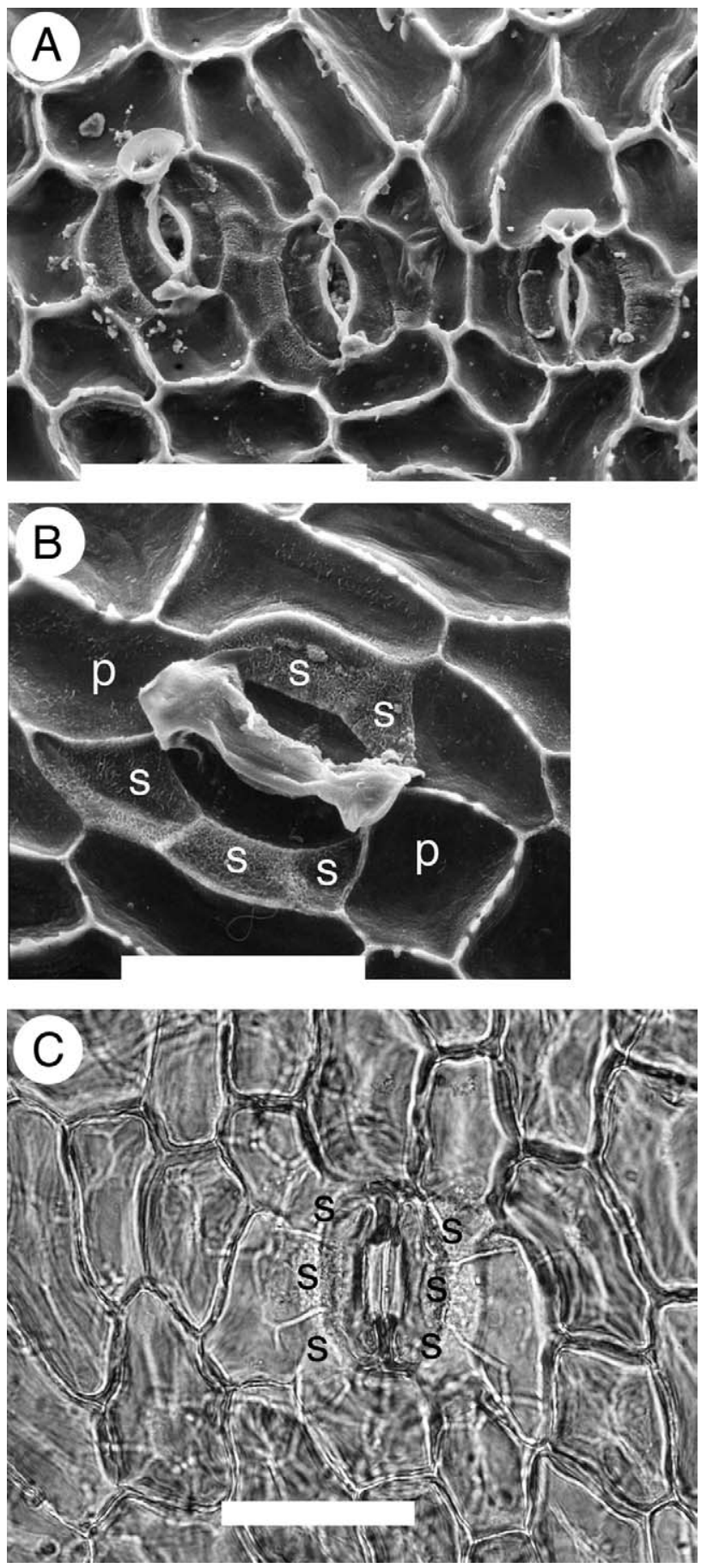

Fig. 5 Images of Bellendena montana cuticles showing stomata. Scale bars $=50 \mu \mathrm{m}$ for $A, C ; 100 \mu \mathrm{m}$ for $B$. A, SEM image showing three stomata. The stomate at left appears to be laterocytic, with a $2+3$ cell arrangement, while that at right may be termed hemiparacytic. The cells between the two stomata at left and center are interpreted as subsidiary cells with shared neighboring cells. The granular regions mark the positions of the subsidiary cells, each with poorly defined walls between the neighboring cells. $B$, SEM image showing a stomate with a $2+3$ laterocytic cell arrangement. The subsidiary cells $(S)$ have poorly defined walls separating them from adjacent epidermal cells. $p=$ polar cells. C, LM showing that although cell wall traces are weak, subsidiary cells $(S)$ underlie the guard cells.
Leaves and the Fossil Record of Platanaceae/Proteaceae

Drinnan et al. (1994) proposed that the Proteaceae could be seen as an ancient Southern Hemisphere vicariant of the abundant and diverse platanoids that populated midCretaceous floras of the Northern Hemisphere. Notwithstanding evidence that the role of platanoids has been overestimated at the expense of Hamamelidaceae (Maslova 2003; Maslova and Herman 2004), the fossil record shows that the range of foliar morphology among extant Platanaceae is only a fraction of that which occurred in the past. Similarly, although extant Proteaceae are a large and diverse family, the fossil pollen record in particular clearly shows a high number of extinctions, at least throughout the Cenozoic (Dettmann and Jarzen 1998). It should thus be expected that "platanoid" Proteaceae (or "proteoid" Platanaceae) leaves will be found. Upchurch (1984) demonstrated that the stomatal and trichome base features of some of the Lower Cretaceous (Albian) trilobed, palinactinodromous leaves from the Potomac Group of the eastern United States (Doyle and Hickey 1976) were entirely consistent with extant Platanaceae, and in many cases, fossil platanoid leaves are found in association with reproductive material consistent with Platanaceae (Crane et al. 1988; Pigg and Stockey 1991; Kvaček et al. 2001; Kvaček and Manchester 2004). Crane et al. (1993) linked platanaceous reproductive structures in the Potomac Group with co-occurrent, pinnate/pinnatifid Sapindopsis leaves, in part because of similar striated cuticles of these leaves and tepals of the fossilized pistillate flowers. However, striated cuticles are widespread in angiosperms, and in our opinion, more evidence is required to confirm whether these leaves and reproductive structures came from the same plants.

As discussed by Johnson and Briggs (1975), the leaves of extant Proteaceae show simple, lobed, deeply divided, or fully pinnate forms, at least at some life stage. Interestingly, some such leaves are very similar in gross morphology to those of fossil Platanaceae leaves. A remarkable example is that between Platanites hebredicus Forbes from the Paleocene of Scotland (Crane et al. 1988) and the juvenile leaves of extant Kermadecia species from New Caledonia (illustrated by Virot 1968). These leaves are compound with shallowly three-lobed terminal leaflets. Details of leaf venation and tooth morphology can be difficult to determine from fossils. However, it is noteworthy that, for example, the fossil species Platanus neptunii (Ett.) Bůžek, Holý \& Kvaček has semicraspedodromous venation with glandular leaf teeth that are convex on their basal sides and straight to concave on the apical sides, with shallowly rounded sinuses (Kvaček and Manchester 2004). This is highly reminiscent of the venation and margin type seen in some extant Proteaceae, such as Knightia excelsa R. Br. and Lomatia fraxinifolia F. Muell. ex Benth. (Hyland et al. 2003).

In the Southern Hemisphere, a number of interesting platanoid leaf fossils have been documented from Cretaceous floras in New Zealand (Pole 1992; Parrish et al. 1998), and Pole (2000) also reported specimens with possible affinity to Platanaceae from an Early Cretaceous flora in Australia. However, none of these fossils can be confidently considered to have close relationships with Platanaceae, especially 
because the more abundant New Zealand material lacks supporting cuticular evidence. Pole (2000) recognized that the cuticular material from Australia was not comparable with extant Platanus but was similar to that of the Potomac $\mathrm{Sa}$ pindopsis (Crane et al. 1993). However, as discussed previously, there is also doubt that Sapindopsis is platanoid. Therefore, in the absence of convincing macrofossils, the strongest evidence at present for the earliest austral Proteales may be the occurrence of the pollen species Tricolpites minutus (Brenner) Dettmann in late Albian-early Cenomanian ( $100 \mathrm{Ma}$ ) sediments (Dettmann 1973; Archangelsky et al. 1994). According to Friis et al. (1988), similar pollen occurs in the anthers of staminate inflorescences of Platanaceae in the late Albian Potomac flora of Maryland. At least in the Southern Hemisphere such grains may not represent Platanaceae but extinct plesiomorphic Proteaceae or stem taxa leading to Proteaceae. The plants that produced T. minutus were evidently part of the second (nonmagnoliid) wave of angiosperms that reached the Australian region at around this time (Dettmann 1994). At present, Triorites africaensis Jardiné \& Magloire is considered to represent the oldest record of Proteaceae pollen (Ward and Doyle 1994), from CenomanianTuronian sediments of northern Gondwana (Africa and South America), as reported for instance by Masure et al. (1998). However, Dettmann and Jarzen (1998) cautioned that to be accepted with greater confidence, grains of T. africaensis that were definitely formed according to Garside's rule would have to be found. In developing pollen tetrads that conform to this rule, the apertures meet in threes at four points, a state known only in Proteaceae and some Olacaceae (Dettmann and Jarzen 1998). Dettmann and Jarzen (1998) interpreted the fossil pollen record as indicating that proteaceous ancestors reached Australia from the north in the Turonian and then underwent a massive diversification and expansion in the Australian-Antarctic region during the Late Cretaceous, including the evolution of crown taxa.

\section{Paleobotanical Implications of This Study}

Our data imply that caution should be exercised in assigning platanoid leaves to Platanaceae, especially in the absence of associated reproductive fossils. In this respect, a similar conclusion was reached by Maslova (2003) and Maslova and Herman (2004). Even in the Northern Hemisphere, isolated leaves with compound trichome bases and nonparacytic stomata could represent plesiomorphic Proteaceae, or stem taxa. In contrast, fossil leaves with brachyparacytic stomata and compound trichome bases can be referred to Proteaceae with confidence, especially if the leaves possess architectural features typical of Proteaceae. Given that similar trichome bases were observed elsewhere in the tricolpate clade, less certainty applies to the referral of dispersed cuticles to Proteaceae. However, most core tricolpates, including those taxa with such trichome bases, exhibit nonparacytic stomata (also data of Nandi et al. [1998]). Some Cenozoic proteaceous taxa from southern Australia (Lange 1978), Tasmania (Jordan et al. 1998), and New Zealand (Pole 1998) are known to exhibit occasional nonparacytic stomata, although at least in the case of the latter two regions, these appear only as normal subsidiary cells with transverse septa. Notwithstanding this, the possibility of plesiomorphic states in extinct taxa should not be discounted, as suggested by Jordan et al. (1998). We anticipate future reports of fossil Proteales that will further clarify relationships within this ancient order. The fossil record is particularly significant for this lineage, given the extensive extinctions that have occurred.

\section{Acknowledgments}

We are indebted to Steven Manchester for providing Platanus specimens and general encouragement. Thanks also to Rosemary Paull. This research was supported by funding from the Australian Research Council.

\section{Literature Cited}

APG II (Angiosperm Phylogeny Group) 2003 An update of the Angiosperm Phylogeny Group classification for the orders and families of flowering plants: APG II. Bot J Linn Soc 141:399-436.

Archangelsky S, ES Bellosi, GA Jalfin, C Perrot 1994 Palynology and alluvial facies from the mid-Cretaceous of Patagonia, subsurface of San Jorge Basin, Argentina. Cretac Res 15:127-142.

Baas P 1969 Comparative anatomy of Platanus kerrii Gagnep. Bot J Linn Soc 62:413-421.

Baranova M 1983 On the laterocytic stomatotype in angiosperms. Brittonia 35:93-102.

Bremer B, K Bremer, N Heidari, P Erixon, RG Olmstead, AA Anderberg, M Kallersjo, E Barkhordarian 2002 Phylogenetics of asterids based on 3 coding and 3 non-coding chloroplast DNA markers and the utility of non-coding DNA at higher taxonomic levels. Mol Phylogenet Evol 24:274-301.

Brett DW 1979 Ontogeny and classification of the stomatal complex in Platanus L. Ann Bot 44:249-251.

Carpenter RJ 1994 Cuticular morphology and aspects of the ecology and fossil history of North Queensland rainforest Proteaceae. Bot J Linn Soc 116:249-303.

Carpenter RJ, GJ Jordan 1997 Early Tertiary macrofossils of Proteaceae from Tasmania. Aust Syst Bot 10:533-563.
Carpenter RJ, GJ Jordan, RS Hill 1994 Banksieaephyllum taylorii (Proteaceae) from the Late Paleocene of New South Wales and its relevance to the origin of Australia's scleromorphic flora. Aust Syst Bot 7:385-392.

Cookson IC, SL Duigan 1950 Fossil Banksieae from Yallourn, Victoria, with notes on the morphology and anatomy of living species. Aust J Sci Res Ser B 3:133-165.

Crane PR, SR Manchester, DL Dilcher 1988 Morphology and phylogenetic significance of the angiosperm Platanites hebredicus from the Palaeocene of Scotland. Palaeontology 31: 503-517.

Crane PR, KR Pedersen, EM Friis, AN Drinnan 1993 Early Cretaceous (early to middle Albian) platanoid inflorescences associated with Sapindopsis leaves from the Potomac group of eastern North America. Syst Bot 18:328-344.

Cronquist A 1981 An integrated system of classification of flowering plants. Columbia University Press, New York.

Den Hartog RM, P Baas 1978 Epidermal characters of the Celastraceae sensu lato. Acta Bot Neerl 27:355-388.

Dettmann ME 1973 Angiospermous pollen from Albian to Turonian sediments of eastern Australia. Spec Publ Geol Soc Aust $4: 3-34$. 
1994 Cretaceous vegetation: the microfossil record. Pages 143-170 in RS Hill, ed. History of the Australian vegetation: Cretaceous to recent. Cambridge University Press, Cambridge.

Dettmann ME, DM Jarzen 1998 The early history of the Proteaceae in Australia: the pollen record. Aust Syst Bot 11:401-438.

Dilcher DL 1974 Approaches to the identification of angiosperm leaf remains. Bot Rev 40:1-157.

Donoghue MJ, JA Doyle 1989 Phylogenetic analysis of angiosperms and the relationships of Hamamelidae. Pages 17-45 in PR Crane, S Blackmore, eds. Evolution, systematics, and fossil history of the Hamamelidae. Vol 1. Clarendon, Oxford.

Douglas AW 1995 Affinities. Pages 6-14 in P McCarthy, ed. Flora of Australia. Vol 16. Eleagnaceae, Proteaceae 1. CSIRO, Melbourne.

Douglas AW, SC Tucker 1996 Comparative floral ontogenies among Persoonioideae including Bellendena (Proteaceae). Am J Bot 83: $1528-1555$.

Doyle JA, PK Endress 2000 Morphological phylogenetic analysis of basal angiosperms: comparison and combination with molecular data. Int J Plant Sci 161(suppl):S121-S153.

Doyle JA, LJ Hickey 1976 Pollen and leaves from the midCretaceous Potomac Group and their bearing on early angiosperm evolution. Pages 139-206 in CB Beck, ed. Origin and early evolution of angiosperms. Columbia University Press, New York.

Doyle JA, CL Hotton 1991 Diversification of early angiosperm pollen in a cladistic context. Pages 169-195 in S Blackmore, SH Barnes, eds. Pollen and spores: patterns of diversification. Clarendon, Oxford.

Drinnan AN, PR Crane, SB Hoot 1994 Patterns of floral evolution in the early diversification of non-magnoliid dicotyledons (eudicots). Plant Syst Evol Suppl 8:93-122.

Endress PK, A Igersheim 1999 Gynoecium diversity and systematics of the basal eudicots. Bot J Linn Soc 130:305-393.

Floyd SK, VT Lerner, WE Friedman 1999 A developmental and evolutionary analysis of embryology in Platanus (Platanaceae), a basal eudicot. Am J Bot 86:1523-1537.

Frenguelli J 1943 Proteáceas del Cenozoico de Patagonia. Notas Mus La Plata 8:201-213.

Friis EM, PR Crane, KR Pedersen 1988 Reproductive structures of Cretaceous Platanaceae. Biol Skrift 31:1-55.

Gonzalez CC, MA Gandolfo, RN Cúneo 2004 Leaf architecture and epidermal characters of the Argentinean species of Proteaceae. Int J Plant Sci 165:521-536.

Hayes V, EL Schneider, S Carlquist 2000 Floral development of Nelumbo nucifera (Nelumbonaceae). Int J Plant Sci 161(suppl): S183-S191.

Hickey LJ, JA Wolfe 1975 The bases of angiosperm phylogeny: vegetative morphology. Ann Mo Bot Gard 62:538-589.

Hill RS, DC Christophel 1988 Tertiary leaves of the tribe Banksieae (Proteaceae) from south-eastern Australia. Bot J Linn Soc 97: 205-227.

Hill RS, GJ Jordan 1993 The evolutionary history of Nothofagus (Nothofagaceae). Aust Syst Bot 6:111-126.

Hill RS, LJ Scriven, GJ Jordan 1995 The fossil record of Australian Proteaceae. Pages 621-630 in P McCarthy, ed. Flora of Australia. Vol 16. Eleagnaceae, Proteaceae 1. CSIRO, Melbourne.

Hilu KW, T Borsch, K Müller, DE Soltis, PS Soltis, V Savolainen, MW Chase, et al 2003 Angiosperm phylogeny based on matK sequence information. Am J Bot 90:1758-1776.

Hoot SB, AW Douglas 1998 Phylogeny of the Proteaceae based on $a t p B$ and $a t p B-r b c L$ intergeneric spacer region sequences. Aust Syst Bot 11:301-320.

Hoot SB, S Magallón, PR Crane 1999 Phylogeny of basal eudicots based on three molecular data sets: $a t p \mathrm{~B}, r b c \mathrm{~L}$, and $18 \mathrm{~S}$ nuclear ribosomal DNA sequences. Ann Mo Bot Gard 86:1-32.
Hyland BPM, T Whiffin, DC Christophel, B Gray, RW Elick 2003 Australian tropical rainforest plants: trees, shrubs and vines. CSIRO, Melbourne.

Johnson LAS, BG Briggs 1975 On the Proteaceae: evolution and classification of a southern family. Bot J Linn Soc 70:83-182.

Jordan GJ, RJ Carpenter, RS Hill 1998 The macrofossil record of Proteaceae in Tasmania: a review with new species. Aust Syst Bot 11:465-501.

Judd WS, RG Olmstead 2004 A survey of tricolpate (eudicot) phylogenetic relationships. Am J Bot 91:1627-1644.

Kim S, DE Soltis, PS Soltis, MJ Zanis, Y Suh 2004 Phylogenetic relationships among early-diverging eudicots based on four genes: were the eudicots ancestrally woody? Mol Phylogenet Evol 31: $16-30$.

Kvaček Z, SR Manchester 2004 Vegetative and reproductive structures of the extinct Platanus neptuni from the Tertiary of Europe and relationships within the Platanaceae. Plant Syst Evol 244:1-29.

Kvaček Z, SR Manchester, S Guo 2001 Trifoloiate leaves of Platanus bella (Heer) comb. n. from the Paleocene of North America, Greenland, and Asia and their relationships among extinct and extant Platanaceae. Int J Plant Sci 162:441-458.

Lange RT 1978 Some Eocene leaf fragments comparable to Proteaceae. J R Soc West Aust 60:107-114.

Leroy J-F 1982 Origine et evolution du genre Platanus (Platanaceae). C R Acad Sci Ser III 295:251-254.

Maslova NP 2003 Extinct and extant Platanaceae and Hamamelidaceae: morphology, systematics and phylogeny. Paleontol J 37(suppl):467-590.

Maslova NP, AB Herman 2004 New finds of fossil Hamamelids and data on the phylogenetic relationships between the Platanaceae and Hamamelidaceae. Paleontol J 38:563-575.

Masure E, R Rauscher, J Dejax, M Schuler, B Ferré 1998 Cretaceous-Paleocene palynology from the Côte d'Ivoire-Ghana transform margin, sites 959, 960, 961, and 962. Pages 253-276 in J Mascle, GP Lohmann, M Moulade, eds. Proceedings of the Ocean Drilling Program. Scientific results. Vol 159. Ocean Drilling Program, College Station, TX.

Metcalfe CR, I Chalk 1979 Anatomy of the dicotyledons. 2nd ed. Vol 1. Systematic anatomy of leaf and stem, with a brief history of the subject. Clarendon, Oxford.

Nandi OI, MW Chase, PK Endress 1998 A combined cladistic analysis of angiosperms using $r b c \mathrm{~L}$ and non-molecular data sets. Ann Mo Bot Gard 85:137-212.

Nixon KC, JM Poole 2003 Revision of the Mexican and Guatemalan species of Platanus (Platanaceae). Lundellia 6:103-137.

Parrish JT, IL Daniel, EM Kennedy, RA Spicer 1998 Paleoclimatic significance of mid-Cretaceous floras from the middle Clarence Valley, New Zealand. Palaios 13:149-159.

Pigg KB, RA Stockey 1991 Platanaceous plants from the Paleocene of Alberta, Canada. Rev Palaeobot Palynol 70:125-146.

Pole MS 1992 Cretaceous macrofloras of eastern Otago, New Zealand: angiosperms. Aust J Bot 40:169-206.

1998 The Proteaceae record in New Zealand. Aust Syst Bot 11:343-372.

2000 Dicotyledonous leaf macrofossils from the latest Albian-earliest Cenomanian of the Eromanga Basin, Queensland, Australia. Paleontol Res 4:39-52.

Savolainen V, MF Fay, DC Albach, A Backlund, M van der Bank, KM Cameron, SA Johnson, et al 2000 Phylogeny of the eudicots: a nearly complete familial analysis based on $r b c L$ gene sequences. Kew Bull 55:257-309.

Schwarzwalder RN, DL Dilcher 1991 Systematic placement of the Platanaceae in the Hamamelidae. Ann Mo Bot Gard 78:962-969.

Soltis DE, AE Senters, MJ Zanis, S Kim, JD Thompson, PS Soltis, LP 
Ronse de Craene, PK Endress, JS Farris 2003 Gunnerales are sister to other core eudicots: implications for the evolution of pentamery. Am J Bot 90:461-470.

Takhtajan AL 1980 Outline of the classification of flowering plants (Magnoliophyta). Bot Rev 46:225-359.

Upchurch GR 1984 Cuticle evolution in Early Cretaceous angiosperms from the Potomac Group of Virginia and Maryland. Ann Mo Bot Gard 71:522-550.

Virot R 1968 Protéacées. Pages 1-254 in A Aubréville, ed. Flore de la
Nouvelle-Calédonie et Dépendances. Vol 2. Muséum National d'Histoire Naturelle, Paris.

Ward JV, JA Doyle 1994 Ultrastructure and relationships of midCretaceous polyporate and triporate pollen from northern Gondwana. Pages 161-172 in MH Kurmann, JA Doyle, eds. Ultrastructure of fossil spores and pollen. Royal Botanic Gardens, Kew.

Wikström N, V Savolainen, MW Chase 2001 Evolution of the angiosperms: calibrating the family tree. Proc R Soc Lond B Biol Sci 268:2211-2220. 